\title{
Teratogenic study of ozone. Possible indications in obstetrics and gynecology
}

\author{
Silvia Menendez-Cepero
}

Collaborator of the National Center for Scientific Research. Havana, Cuba.

\section{ABSTRACT}

O Open Access

\section{Citation}

Menendez-Cepero S. Teratogenic study of ozone. Possible indications in obstetrics and gynecology [abstract]. Proceedings of the 5Th WFOT Meeting; 2016 Nov 18-20; Mumbai, India. J Ozone Ther. 2018;2(2). doi: 10.7203/ jo3t.2.2.2018.11129

\section{Academic Editor}

Jose Baeza-Noci, School of Medicine, Valencia University, SPAIN

\section{Editor}

World Federation of Ozone Therapy, Bolgna, ITALY

\section{Received}

December 10, 2017

\section{Accepted}

December 11, 2017

\section{Published}

March 4, 2018

\section{Intellectual Property}

Silvia Menendez-Cepero.

This is an open access article distributed under the terms of the Creative Commons Attribution License (CC BY 4.0), which permits unrestricted use, distribution, and reproduction in any medium, provided the original author and source are credited.

\section{Author Information}

silviamenendez@infomed.sld.cu
Ozone is a powerful oxidant, surpassed, in this regard, only by fluorine. Its doubtless strong reactivity has contributed to establish the dogma that ozone is always toxic and its medical application must be proscribed. However, ozone therapy has been used for therapeutic purposes since the beginning of the last century and its use is increasingly demanded nowadays [1]. For proper enlightenment and guidance of the person interested in the use of ozone for medical purposes, scientific documentation on the safety/toxicity profile of this acclaimed procedure becomes necessary.

Taking into account that the National Health Regulatory Agencies require of documentation with scientific trials for sanitary registration of drugs and therapy procedures, different toxicological tests were performed in Cuba using experimental animals, following the guidelines from the Cuban Regulatory Agency, Food Drug Administration, International Standards Organization and the Health World Organization aimed at proving the safety of ozone therapy administration.

In this lecture, the teratogenic study of ozone by rectal insufflation (RI) is presented [2]. Female Wistar rats $(200-250 \mathrm{~g})$ were divided into 3 experimental groups: 1 - control $(n=15)$, without any treatment; 2 - treated with $1 \mathrm{~mL}$ of ozone $(\mathrm{n}=17)$ at a concentration of $34 \mu \mathrm{g} / \mathrm{mL}(150 \mu \mathrm{g} / \mathrm{kg}) ; 3-$ treated with $4 \mathrm{~mL}$ of ozone $(n=17)$ at a concentration of $90 \mu \mathrm{g} / \mathrm{mL}(1600 \mu \mathrm{g} /$ $\mathrm{kg}$ ). Ozone was administered by RI during 10 sessions, from the 6th to the 15 th day of gestation. The pregnancy was confirmed by the presence of spermatozoa in the vaginal exudates. It was considered that the animals with positive exudates were in the 0 day of gestation. In the 19th day of gestation, animals were euthanized by an ether overdose and the fetuses were obtained by cesarean. The number of corpus luteum, implantations, alive and dead fetuses, reabsorptions, as well as the weight and the length cranium-caudal of each fetus were registered. Alive fetuses were examined to find any external malformations.

No toxic effect was observed in the pregnant rats subjected to the ozone treatment by RI. Mother weight gain did not show significant differences among the groups, neither the other indicators (number of corpus luteum, implantations, alive and dead fetus, reabsorptions).

In respect to the fetus morphology, no external, skeletal or visceral malformations were observed. The weight and the length cranium-causal did not show significant differences among the groups. It is concluded that no teratogenic nor embriotoxic effects were found after the ozone application by rectal insufflation at the doses studied.

With respect to the application of ozone therapy in Obstetrics, an update of 
the papers published about this topic was presented [3-6]. They referred the use of ozone therapy in: pregnant womens with hypertension, genital or no genital infections during pregnancy, threatened abortion, intrauterine fetal hypoxia, among others. For example, the effect of ozone therapy by rectal insufflation on fetoplacental blood flow in hypertensive pregnant women, with 24 weeks of gestation, indicated a better fetoplacental blood flow, achieving a greater oxygenation in the group treated with ozone plus antihypertensive treatment (methyldopa) in comparison with a control group treated only with the conventional treatment. Also, a reduction of methyldopa in $23.7 \%$ of the initial doses was found in the ozone group as opposed to an increase of $40.8 \%$ in the control group. Another study about ozone therapy as the main component of the complex treatment of threatened abortion, using ozonated saline solution in the first (group I) or second semester (group II) showed a decrease in the molecular products of lipid peroxidation and a simultaneous increase in the antioxidant activity.

Also, with ozone therapy the pregnancy was preserved and prolonged to the physiological terms of labor in $86 \%$ of patients inside group I and in $85 \%$ of patients inside group II. However, in the control group (conventional treatment) I and II, it was possible to preserve the pregnancy in 65 and $60 \%$ of cases, respectively. In the ozone group, $80 \%$ of newborn babies received 7-10 points (maximum value) according to Apgar's score, however, only $58.3 \%$ in the control group.

In Gynecology, an interesting paper was reviewed about distal fallopian tube recanalization using ozone treatment. In the ozone group, the ozone was introduced in the uterine cavity and in the case of the control group, antiinflammatory drugs and antibiotics was used. The overall recanalization rate was significantly higher in the ozone group (93\%) as compared to the control group $(79 \%) 6$-months after intervention $(p<0.01)$. The re-adhesion rate in the ozone group was significantly lower than the control group $(p<$ 0.01). The pregnancy rate after 12 months of intervention was significantly higher in the ozone group (59\%) compared to the control group (43\%) ( $p<$ 0.05 ). These results were highly encouraging and hold promise for treating distal tubal obstruction in infertile females.

For inflammatory diseases in female genital organs, intravaginal ozone has been used. Ozone restores the body's own defense abilities by the normalization of vaginal mucosa local immunity, prevents the generalization of inflammatory processes, facilitates uterus healing, reduces the treatment time with no complications or side effects.

In Cuba we have a vast experience in the use of ozonated sunflower oil in the treatment of vulvovaginitis, human papillomavirus, acuminate condyloma, genitalis herpes virus with very good results [7-9].

In summary, we can state that preclinical and clinical studies presented here about the application of ozone therapy in Obstetrics and Gynecology, in the different ways of ozone applications, do not demonstrate any adverse effect or complication. However, more controlled clinical trials are necessary to perform in order to prove the inocuity of ozone therapy, mainly in Obstetrics, where there are still questions to be clarified.

Keywords: ozone therapy, teratogenic study, gynecology, obstetrics, ozonated sunflower oil, vulvovaginitis, human papillomavirus, threatened abortion, fetal hypoxia.

\section{References:}

1. Menendez S, Gonzalez R, Ledea OE, Leon OS, Hernandez F, Diaz M . Ozonoterapia: Aspectos basicos y aplicaciones clinicas. La Habana, Cuba: Editorial CENIC; 2008. 
2. Rodriguez MD, Menendez S, Gomez M, Garcia H. Estudio teratogenico del ozono administrado por insuflacion rectal a ratas wistar. Revista CENIC Ciencias Biologicas. 1989;20(1-2-3):28-32.

3. He C, Ma XP. Distal fallopian tube recanalization using ozone treatment: a clinical study in two hundred tubal obstruction Chinese patients. Int J Clin Exp Med. 2015;8(2):2958-2961

4. Tanbouli T, Mawsouf MN, Re L, Martinez-Sanchez G, Saaed G, El-Badry $\mathrm{SM}$, et al. Effect of Ozone Therapy on Foetoplacental Blood Flow in Hypertensive Pregnant Women. Int J Ozone Ther. 2009;8(2):211-216.

5. Grechkanev GO, Motovilova M, Ponomareva IV. Ozonetherapy for the treatment of endometritis. Revista Española de Ozonoterapia. 2014;4(1): 69-72.

6. Grechkanev GO, Chandra-D’Mello R, Schwartz-Tapia A. Ozonetherapy in a Complex Treatment of Tubal Peritoneal Sterility. Revista Española de Ozonoterapia. 2012;2(suppl 1):1.

7. Falcon L, Menendez S, Daniel R, Garbayo E, Moya S, Abreu M. Aceite ozonizado en Dermatologia. Experiencia de 9 años. Revista CENIC Ciencias Biologicas. 1998;29(3):192-195.

8. Grillo R, Falcon L, Menendez S. Tratamiento de herpes simple genital con aceite ozonizado. Estudio Preliminar. Revista Cubana de Medicina Militar. 1990;4(1):62-66.

9. Lezcano IJ, Molerio M, Gomez M, Contreras R, Roura G, Diaz W. Actividad in vitro del OLEOZON frente a agentes etiologicos de infecciones de la piel. Revista CENIC Ciencias Biologicas. 1998;29(3): 209-212. 